\title{
Causes of short stature in Iraqi hospital based study patients
}

\author{
Munib A. AIZubaidi* FICMS (Ped) \\ Maher M. Saleh** FICMS (Ped) \\ Zahraa M. Jawad*** FICMS (Ped)
}

\section{Abstract:}

Backgrounds: Growth is an important objective parameter of general health of the child. Normal growth requires adequate nutrition along with various hormonal stimuli. Short stature is a common cause of referral to pediatric endocrinologists.

Objectives: To find the causes of short stature in patients referred to pediatric endocrinology clinic of children welfare teaching hospital, the significance of bone age assessment and the variation of growth hormone level in these patients.

JFac Med Baghdad

Patients and methods: This prospective study was carried out in the endocrine clinic of Children

2017; Vol.59, No .3

Receive May 2017

Accepted Aug.2017

Welfare Teaching Hospital/Medical City over ten months period, included 150 patients. A proper detailed medical history was taken, physical examination performed included growth parameters, and general investigations with bone age, thyroid function test, celiac screening and growth hormone level were done for all patients. Growth hormone stimulation test was done when indicated and phenotype, Karyotyping was done in selected cases.

Result: The total number of patients included in this study was 150 , ranging from $\geq 2$ to 16 years old, and the male to female ratio was 1.14:1.The relationship between age and gender is significant(p-value 0.04).The commonest etiology was endocrine causes in 92(61.33\%), non-endocrine causes in $34(22.67 \%)$ and normal variant in 24(16\%) patients. Bone age was delayed in 86(57.33\%) and normal in $6(4 \%)$ of endocrine cause which is highly significant ( $\mathrm{p}$-value $<0.001$ ), and in non-endocrine causes it was delayed in $24(16 \%)$ and not delayed in $10(6.67 \%)$ patients which is significant (p-value $<0.01$ ). Growth hormone level was deficient in $80(53.33 \%)$ patients of endocrine causes of short stature which is highly significant (p-value $<0.001 \%$ ), and deficient in $15(10 \%)$ patients of non-endocrine causes which is significant ( $\mathrm{p}$-value $<0.03 \%)$.

Conclusions: Growth hormone deficiency, familial short stature and constitutional growth delay were the leading causes of short stature in patients referred .Growth hormone deficiency is the commonest cause of short stature in those patients, bone age is a corner stone in evaluating short stature and it gets delayed in some cases with systemic and endocrine causes other than growth hormone deficiency and constitutional growth delay.

Keywords: Growth hormone, Growth retardation, bone age, short stature.

\section{Introduction:}

Short stature (SS), defined as a height of more than two standard deviations below the average for same age and sex, and it is one of the most common causes of referrals to pediatric endocrinologists(1). Normal growth requires adequate nutrition along with various hormonal stimuli. The important hormones are: growth hormone $(\mathrm{GH})$, insulin-like growth factor (IGF)-1, thyroid hormones, sex steroids and other growth factors (2). Linear growth is maximum during infancy; $25 \mathrm{~cm}$ in first year, 10 $\mathrm{cm} /$ year in next 2 years. Subsequently, it gradually declines to $6-7 \mathrm{~cm} /$ year till puberty when again growth accelerates in sigmoid manner when it is around $10 \mathrm{~cm} /$ year (2). Bone age: a bone age assessment provides an estimate of a child's skeletal maturation by assessing the ossification of the epiphyseal centers. 3 CAUSES OF SHORT STATURE: Table (1) 4, 5 Normal variants of growth: Constitutional growth delay, Familial short stature Endocrinological causes: Growth hormone deficiency, Hypothalamic/pituitary irradiation, Hypothyroidism,

*Department of Pediatric, college of medicine Baghdad University

**Children Welfare Teaching Hospital.

Corresponding Email: MahermahdiB@yahoo.com

***Karbalaa teaching hospital of pediatrics
Congenital adrenal hyperplasia, Laron syndrome, Diabetes mellitus, Central diabetes insipidus, Pseudohypoparathyroidism. Non-Endocrinological causes: Celiac disease, Malnutrition, Genetic syndromes, Skeletal dysplasia and rickets, IUGR, Congenital heart disease, Chronic anemia and malabsorption, Renal tubular acidosis, Psychosocial dwarfism, Chronic renal failure, Bronchial asthma, Duchene muscular dystrophy, Cerebral palsy, Cystic fibrosis, Bartter syndrome, Drugs and radiotherapy effect, Glucocorticoid excess, Hypophosphatemic vitamin D resistant rickets. Causes of short stature are diverse, but fortunately the most common causes beyond the first two years of life are Familial Short Stature (FSS) and Constitutional Growth Delay CGD 6. Assessment of the child with short stature who visit endocrine clinic: by history, Physical Examination and full investigation, however, short stature is not necessarily a sign of a health problem7. Management options for a child with short stature would depend on the underlying cause. Short stature secondary to any systemic illness will not reverse unless the underlying cause is evaluated and treated accordingly 8 . Since malnutrition is a major cause of short stature in developing countries, optimization of nutritional status with appropriate dietary advice or nutritional therapy should be included in the 
management8 adequate vitamin D replacement in rickets and adequate inhaled/oral medication in chronic asthma and identifying and treating the cause of excess in cushing syndrome is the key to restoring normal growth9.

\section{Patients and Methods:}

This prospective study was carried out over ten months period(from the first of March 2013 till the end of December 2013).It included 150 child who referred to outpatient pediatric endocrinology clinic of Children Welfare Teaching Hospital/Medical City as a case of short stature. The inclusion criteria were: short stature (height $<3$ th percentile) and age from $>2-16$ years. The following demographic data were collected: name, sex, age (date of birth), date of presentation, gestational age, and birth weight and parents height.Thorough history and Physical Examination were taken from each patient to identify any systemic illness which may affect the height of the patient.Measurement of weight and height, the height was measured with the patient in bare-footed with the heels in the same upright plane as the back of the head, using an accurately calibrated stadiometer, mid parental height measured by these formula:

Boys height $=$ [father's height $(\mathrm{cm})+$ (mother's height $(\mathrm{cm})+13] \div 2$

Girls height $=[($ father's height $(\mathrm{cm})-13)+$ mother's height $(\mathrm{cm})] \div 2$

Patients with a height $<3$ percentile for same sex and age, underwent complete laboratory evaluation including: CBC, blood urea, serum creatinine level, serum electrolytes and alkaline phosphate, urine analysis and culture, thyroid function tests. X-ray of the left hand for bone age, Bone age was determined in all cases by radiological assessment of the epiphyseal maturation or shapes of bones of the left hand. and measured using R.U.S (Redius. Ulna. short stature Short bones) chart. Systemic disorders were diagnosed by appropriately selected laboratory tests, cases of malnutrition were diagnosed by detailed workup for malabsorptive conditions. Patients with a height $<3$ percentile, Tanner white house 2 method (TW2) , apart from those with familial short stature and constitutional delay of growth underwent $\mathrm{GH}$ provocative test which was done either in the National Diabetic Center or in a private laboratory. Using clonidine provocative tests following an overnight fast. with dose of $75-100 \mu \mathrm{g} / \mathrm{m}^{2}$ if the peak growth hormone concentration failed to reach $10 \mathrm{ng} / \mathrm{mL}$ after $1 / 2,1,2$ hours GH deficiency can be confirmed. Those patients with extreme short stature and delayed bone age with high growth hormone level was suspected to have Laron's syndrome so they sent for IGF-1 levels estimation in National Diabetic Center. Those short patients with normal investigation, their high within prenatal high and bone age and assess height to mid parental height classified as familial short stature, but those with delay bone age classified as constitutional growth delay.

\section{Result:}

The total number of patients included in this study was 150 patients, 80 of them were male and the other 70 were female with the male: female ratio of 1.14: 1 . Their age ranges from $>2-16$ years with mean age of 9.7 $\pm 3.4 \mathrm{SD}$ and median age of $10.1 \pm$ 3.4SD The majority of patients were between 5-15 years 121(80.67\%) (Table 2) The relationship between age and gender with significant (p-value 0.04 ), the age between 5-10 years short stature is highly prevalent in females, but between $10-15$ years the short stature is high prevalent in males.

Table (2): distribution of patients according to their age and gender

\begin{tabular}{lllllll}
\hline Age & male & $\%$ & female & $\%$ & total & $\%$ \\
\hline$\leq 5$ & 14 & $9.33 \%$ & 9 & $6 \%$ & 23 & $15.33 \%$ \\
\hline$>5-10$ & 28 & $18.67 \%$ & 35 & $23.33 \%$ & 63 & $42 \%$ \\
\hline$>10-15$ & 32 & $21.33 \%$ & 26 & $17.33 \%$ & 58 & $38.67 \%$ \\
\hline$>15$ & 6 & $4 \%$ & 0 & $0 \%$ & 6 & $4 \%$ \\
\hline Total & 80 & $53.33 \%$ & 70 & $46.67 \%$ & 150 & $100 \%$ \\
\hline
\end{tabular}

The major groups for causes of short stature in these patients were endocrine causes in $92(61.33 \%)$, nonendocrine causes in 34(22.67\%) patients and normal variant (familial short stature and constitutional growth delay) 24 (16\%) patients. (Table 3 )

Table (3) Etiology of short stature in 150 short children.

\begin{tabular}{lll}
\hline Causes & No. & $\%$ \\
\hline Normal variant & 11 & \\
\hline Familial short stature & 13 & $8.33 \%$ \\
\hline Constitutional growth delay & 24 & $16 \%$ \\
\hline Total & & \\
\hline Endocrine causes & 77 & $51.33 \%$ \\
\hline Growth hormone deficiency & 4 & $2.67 \%$ \\
\hline Hypothyroidism & 4 & $2.67 \%$ \\
\hline Diabetes mellitus & 2 & $1.33 \%$ \\
\hline Laron syndrome & 2 & $1.33 \%$ \\
\hline Congenital adrenal hyperplasia & 2 & $1.33 \%$ \\
\hline Precocious puberty & 1 & $0.67 \%$ \\
\hline Pseudohypoparathyroidism & 92 & $61.33 \%$ \\
\hline Total & & \\
\hline Non endocrine causes & 9 & $6 \%$ \\
\hline Celiac disease & 6 & $4 \%$ \\
\hline Skeletal deformity & 4 & $2.67 \%$ \\
\hline Turner syndrome & 4 & $2.67 \%$ \\
\hline Chronic renal disease & 2 & $1.33 \%$ \\
\hline Asthma use of steroid & 2 & $1.33 \%$ \\
\hline Silver russel syndrome & 2 & $1.33 \%$ \\
\hline Prader willi syndrome & 1 & $0.67 \%$ \\
\hline Nephrotic syndrome use of steroid & 1 & $0.67 \%$ \\
\hline Renal tubular acidosis & 1 & $0.67 \%$ \\
\hline Hypophosphatemic Rickets & 1 & $0.67 \%$ \\
\hline Noonan syndrome & 1 & $0.67 \%$ \\
\hline Glycogen storage disease & 34 & $22.67 \%$ \\
\hline Total & & \\
\hline & & \\
\hline
\end{tabular}

Regarding bone age, it was normal in patients with familial short stature and delayed in all patients with constitutional growth delay, while in endocrine causes, it was delayed in $86(57.33 \%)$ and not delayed in $6(4 \%)$ which is highly significant $(\mathrm{P}$ value <0.001). In patients with non-endocrine causes, bone age was delayed in 24(16\%) and not delayed in $10(6.67 \%)$ which is statistically significant (p-value $<0.01 \%$ ) (Table 4$)$. 
Table (4): classification of causes of short stature according to Bone age.

\begin{tabular}{|c|c|c|c|c|}
\hline Causes & $\begin{array}{l}\text { Normal } \\
\text { Bone age }\end{array}$ & $\%$ & $\begin{array}{l}\text { Delayed } \\
\text { Bone age }\end{array}$ & $\%$ \\
\hline \multicolumn{5}{|l|}{ Normal variant } \\
\hline $\begin{array}{ll}\begin{array}{l}\text { Familial short } \\
\text { stature }\end{array} & \\
\end{array}$ & 11 & 7.33 & & \\
\hline $\begin{array}{l}\text { Constitutional } \\
\text { growth delay }\end{array}$ & & & 13 & 8.67 \\
\hline Total & 11 & 7.33 & 13 & 8.67 \\
\hline \multicolumn{5}{|l|}{ Endocrine cause: } \\
\hline $\begin{array}{l}\text { Growth hormone } \\
\text { deficiency }\end{array}$ & & & 77 & 51.33 \\
\hline Hypothyroidism & & & 4 & 2.67 \\
\hline Diabetes mellitus & 1 & 0.67 & 3 & 2 \\
\hline Laron syndrome & & & 2 & 1.33 \\
\hline $\begin{array}{l}\text { Congenital adrenal } \\
\text { hyperplasia }\end{array}$ & 2 & 1.33 & & \\
\hline Precocious puberty & 2 & 1.33 & & \\
\hline $\begin{array}{l}\text { Pseudohypoparathyr } \\
\text { oidism }\end{array}$ & 1 & 0.67 & & \\
\hline Total & 6 & 4 & 86 & 57.33 \\
\hline \multicolumn{5}{|l|}{ Non-endocrine cause: } \\
\hline Celiac disease & 3 & 2 & 6 & 4 \\
\hline Skeletal deformity & 6 & 4 & & \\
\hline Turner syndrome & & & 4 & 2.67 \\
\hline $\begin{array}{ll}\begin{array}{l}\text { Chronic } \\
\text { disease }\end{array} & \text { renal } \\
\end{array}$ & & & 4 & 2.67 \\
\hline Ashma steroid used & & & 2 & 1.33 \\
\hline $\begin{array}{l}\text { Silver-russel } \\
\text { syndrome }\end{array}$ & & & 2 & 1.33 \\
\hline $\begin{array}{ll}\begin{array}{l}\text { Prader } \\
\text { syndrome }\end{array} & \text { willi } \\
\end{array}$ & & & 2 & 1.33 \\
\hline $\begin{array}{l}\text { Nephrotic syndrome } \\
\text { and steroid used }\end{array}$ & & & 1 & 0.67 \\
\hline $\begin{array}{ll}\text { Renal tubular } \\
\text { acidosis }\end{array}$ & & & 1 & 0.67 \\
\hline $\begin{array}{l}\text { Hypophosphatemic } \\
\text { Rickets }\end{array}$ & & & 1 & 0.67 \\
\hline Noonan syndrome & & & 1 & 0.67 \\
\hline $\begin{array}{ll}\begin{array}{l}\text { Glycogen } \\
\text { disease }\end{array} & \text { storage } \\
\end{array}$ & 1 & 0.67 & & \\
\hline Total & 10 & 6.67 & 24 & 16 \\
\hline
\end{tabular}

Table (5): classification of causes of short stature occording to level of GH.

\begin{tabular}{|c|c|c|c|c|}
\hline \multicolumn{5}{|l|}{ Endocrine cause } \\
\hline Growth hormone deficiency & & & 77 & $51.33 \%$ \\
\hline Hypothyroidism & 2 & $1.33 \%$ & 2 & $1.33 \%$ \\
\hline Diabetes mellitus & 3 & $2 \%$ & 1 & $0.67 \%$ \\
\hline Laron syndrome & 2 & $1.33 \%$ & & \\
\hline Congenital adrenal hyperplasia & 2 & $1.33 \%$ & & \\
\hline Precocious puberty & 2 & $1.33 \%$ & & \\
\hline Pseudohypoparathyroidism & 1 & $0.67 \%$ & & \\
\hline Total & 12 & $8 \%$ & 80 & $53.33 \%$ \\
\hline \multicolumn{5}{|l|}{ Non-endocrine cause } \\
\hline Celiac disease & 3 & $2 \%$ & 6 & $4 \%$ \\
\hline Skeletal deformity & 6 & $4 \%$ & & \\
\hline Turner syndrome & 1 & $0.67 \%$ & 3 & $2 \%$ \\
\hline Chronic renal disease & 4 & $2.67 \%$ & & \\
\hline Ashma and Steroid used & 1 & $0.67 \%$ & 1 & $0.67 \%$ \\
\hline Silver-russel syndrome & 2 & $1.33 \%$ & & \\
\hline Prader willi syndrome & & & 2 & $1.33 \%$ \\
\hline $\begin{array}{lll}\begin{array}{l}\text { Nephrotic } \\
\text { steroid used }\end{array} & \text { syndrome } & \text { and } \\
\end{array}$ & & & 1 & $0.67 \%$ \\
\hline Renal tubular acidosis & & & 1 & $0.67 \%$ \\
\hline Hypophosphatemic Rickets & 1 & $0.67 \%$ & & \\
\hline Noonan syndrome & & & 1 & $0.67 \%$ \\
\hline Glycogen storage disease & 1 & $0.67 \%$ & & \\
\hline Total & 19 & $\begin{array}{l}12.67 \\
\%\end{array}$ & 15 & $10 \%$ \\
\hline
\end{tabular}

Growth hormone level in stimulation test was low in $80(53.33 \%)$ and normal in $12(8 \%)$ in patients with endocrine cause of short stature which is highly significant ( $p$-value $<0.001 \%)$. The level of growth hormone was deficient in $15(10 \%)$ and normal in $19(12.67 \%)$ patients with non-endocrine causes for short stature which is statistically significant ( $\mathrm{p}$ value $<0.03 \%$ ). (Table 5 )

\section{Discussion:}

In this study there were no significant differences between males and females with short stature, this is similar to a study done in East Azerbaijan, Iran 10 and in Kingdom Saudi Arabia11. In this study (84\%) of patients with short stature had pathological cause, and $(16 \%)$ of cases had non pathological cause (FSS or CGD), this differ from a study done in Iran in which non pathological cause was $65 \% 12$ and a study done in Kingdom Saudi Arabia non pathological cause was $51.8 \% 11$ In this study GHD, CGD and FSS were the most frequent causes of short stature that are in agreement with worldwide studies 10,12,13 making the GHD, the leading cause of short stature $(51.33 \%)$ which is higher than in other studies as in Iran 23.4\% 13, in kingdom Saudi Arabia 21.8\% 11,in Pakistan 13.9\% 14 in Indian $7.9 \% 15$ and in Taiwan 7.9\% 16.It must be noted that those studies were conducted in the endocrine referral centers; therefore, the prevalence of endocrine disorders, especially GHD, is found to be high in those studies especially in this study as patients only referred after exclusion of nonendocrine causes. In this study, GHD was more common in boys, which is comparable to a study done in Iran13. Other important endocrinological cause was hypothyroidism, which is diagnosed in 4 cases $(2.67 \%)$ of short stature and this is similar to a study done in Pakistan 5.6\% 4 and lower than a study done in Saudi Arabia 18.7\% 11. In this study the most common non endocrinological causes were celiac disease $(6 \%)$, these results were consistent with many worldwide studies 17, in Pakistan 6.5\% 4 and different from high prevalence of the disease in the Saudi Arabian community, with short stature being the only presenting symptoms of celiac disease $14.2 \%$ 11.this may be due to earlier diagnosis of this disease by the general consultation clinic and referral to gastrointestinal clinic. in this study, renal tubular acidosis (RTA) constitute only $0.67 \%$ of cases of short stature, which is lower than that reported in a study done in Iran in which renal tubular acidosis was the commonest non endocrinological causes 13 but few rare cases of multiple growth abnormality and abnormal faces. Turner syndrome was present only in 4 girls $(4.67 \%$ ) which is lower than from what is reported in other studies 18 in Saudi arabia14.2\% 11. In this study achondroplasia was the most frequent cause of disproportionate short stature which is similar to a study done in Iran13. Bone age was assessed in all patients included in the study, and was delayed in123 cases (82\%), including all patients with GHD19, constitutional growth delay 20, Laron syndrome 21, hypothyroidism 22, Turner syndrome23 ,CRF 24, all syndromatic cases Prader 
willi syndrome 25 , Russel silver syndrome 26, Noonan syndrome 27 , RTA 28, Rickets 29 and those who used steroid for long duration had delayed bone age as a study in Turkey 30, in T1DM, 3 of 4 cases had delayed bone age, similar to a study done in Germany 31 and in celiac disease 6 of 9 cases have delayed bone age similar to a study done in Turkey 32. Bone age was normal in 27cases (18\%) all cases of familial short stature 33, pseudohypoparathyroidism 34, and skeletal deformity 35and glycogen storage disease. In this study growth hormone was deficient in 18 cases $(12 \%)$ other than isolated growth hormone deficiency .2 of 4 cases with hypothyroidism had GHD which may be due to panhypopituitarism , which is similar to a study done in USA 36 , within 4 cases of T1DM one have Mauriac syndrome and have GHD which is similar to study done in India 37,6 of 9 cases with celiac disease had GHD that is due to autoimmune involvement of the pituitary gland in patients with celiac disease, which is similar to a study done in Italia 38, in Turner syndrome 3 of 4 cases had GHD that may be due to growth hormone cell auto-antibodies have demonstrated in the serum of a girl with an iso-chromosome variant of Turner's syndrome which is similar to a study done in London 39, and the patient with RTA also had GHD that due to metabolic acidosis affects growth hormone secretion and expression which is similar to a study done in USA, Asturias, Spain 40,three of patients who used steroid for long duration due to their illness 2 had GHD that due to systemic corticosteroids may inhibit growth hormone secretion and reduce growth hormone receptor which is similar to a study done in Denmark 41, regarding genetic syndromes,in Prader Willi syndrome 2 cases presented with GHD similar to a study done in Switzerland that decreasing growth velocity despite the onset of obesity, reduced lean body mass in the presence of adiposity, relatively low insulin-like growth factor-I and low insulin levels, as well as the dramatic effect of $\mathrm{GH}$ treatment on growth, support the presence of hypothalamic GHD in PWS 42 and one case of Noonan syndrome has GHD recent studies of growth hormone secretory pattern provide a new category of growth hormone neurosecretory dysfunction to characterize short stature in Noonan syndrome 43. Patients with chronic renal failure have normal $\mathrm{GH}$, that the Renal failure is a state of GH resistance and not GH deficiency a study done in Germany 44 and 2 cases of short stature who have Silver-Russel syndrome have normal $\mathrm{GH}$ but growth hormone deficiency is not uncommon in silver russel syndrome 45, and in all 6 cases of skeletal dysplasia46 and in a case of hypophosphatemic rickets has normal $\mathrm{GH} 47$

\section{Conclusion:}

Growth hormone deficiency, familial short stature and constitutional growth delay were the leading causes of short stature in children referred to endocrinology
Bone age was delayed in all patients with growth hormone deficiency, constitutional growth delay, hypothyroidism and some patients with systemic and non-endocrine causes of short stature.

\section{References:}

1. Wudy SA,Hagemann S,Dempfel A,et al.Children with idiopathic short stature are poor eaters and have decreased body mass index.Pediatrics.2005;116(1):52-7.

2. Nath P, Kumar J, Hammadur SK, Madhukar Rai.Short Stature: Evaluation and Management.chapter137.2013:626.

3. Gilsanz $V$,Ratib O. Bone Development.In: GilsanzV,Ratib O.Hand Bone Age.A Digital Atlas of Skeletal Maturity. Springer-Verlag Berlin Heidelberg, Germany.2005;2-5.

4. Sultan M, Afza M, Mahmood SH.Etiology of Short Stature in Children Journal of the College of Physicians and Surgeons Pakistan.2008, Vol. 18 (8): 493-497.

5. Parks J. Felner EI. Hypopituitarism.In Kligman R,Stant B,Schor N,et al. Nelson Textbook of Pediatrics, $19^{\text {th }}$ edition.USA.2011,1880

6. Lam WF, Hau WL, Lam TS. Evaluation of referrals for genetic investigation of short stature in Hong Kong. Chin Med J (Engl) 2002;115:607-11.

7. van Gool SA, Kamp GA, Odink RJ, et al. Highdose GH treatment limited to the prepubertal period in young children with idiopathic short stature does not increase adult height. Eur J Endocrinol. 2010 Apr;162 (4) : 653-60.

8. Jayasena YA,Dharshini $K, \quad K \quad S \quad H \quad d e$ Silva,Evaluation and management of short stature in children,Sri Lanka Journal of Diabetes Endocrinology and Metabolism 2011; 1: 30-33 .

9. Massoud A,Endocrine Disorder.In Bannon MJ, Carter Y, Practical Paediatric Problems in Primary Care. UK 2007; 285.

10. Shiva S, Nikzad A. Etiology of short stature in East Azerbaijan, Iran. Iran J Pediatr. 2009;19:3540.

11. Nasir A.,Mohamed SH., Hessah M., et al.Short stature in children: Pattern and frequency in a pediatric clinic, Riyadh, Saudi Arabia .Sudanese J Paed.2012; Vol 12, Issue (1).

12. Mohammadian S, Khoddam H. An etiologic evaluation of children with short stature in Gorgan (North east Iran), 2005. J Med Sci. 2007;7:1206-9.

13. Moayeri H, Aghighi $Y$. A prospective study of etiology of short stature in 426 short children and adolescents. Arch Iranian Med. 2004;7:23-7.

14. Awan TM, Sattar A, Khattak EG. Frequency of growth hormone deficiency in short statured children. J Coll Physicians Surg Pak 2005; 15:2958.

15. Bhadada SK, Agrawal NK, Singh SK, Agrawal $J K$. Etiological profile of short stature. Indian $J$ Paediatr 2003; 70:545-7.

16. Shu SG, Chen YD, Chi CS. Clinical evaluation of short children referred by school screening: an analysis of 655 children.Acta Paediatr Taiwan 2002; 43:340-4. 
17. Queiroz MS, Nery M, Cançado EL, et al.Prevalence of celiac disease in Brazilian children of short stature. Braz J Med Biol Res 2004; 37:5560.

18. Parvin M, Roche E, Costigan C, Hoey HM. Treatment outcome in Turner syndrome. Ir Med J 2004; 97:12, 14-5.

19. Parks JS,Felner EI. Hypopituitarism .In Kligman R,Stant B,Schor N. Nelson Textbook of pediatrics, $19^{\text {th }}$ ed.USA.2011,1879-1880.

20. Ali O,Patricia A. Donohoue. Hypofunction of the Testes. In Kligman R,Stant B,Schor N. Nelson Textbook of pediatrics, $19^{\text {th }}$ ed.USA.2011.1945-46.

21. Allan DB, Rose SR, Reiter EO. Normal growth and growth disorders In: Kappy MS, Allen DB, Geffner M, eds. Principles and Practice of Pediatric Endocrinology. Springfield, IL: Charles C Thomas; 2005:77-211.

22. PP, Philip R, Toms A, Gupta K.Radiological manifestations of juvenile hypothyroidism.Thyroid research and practice.2012,vol9(3),102-104.

23. Alman BA.Goldberg MI.syndromes of orthopaedic importance.In: Lovell WW, WinterB, Morrissy RT, et al.Lovell and Winter's Pediatric Orthopaedics, $6^{\text {th }}$ ed, Vol 1.USA.2006.282-83.

24. Miall L,Rudolf M,Smith D.Growth,Endocrine and metabolism.In: Miall L,Rudolf M,Smith D.Paediatrics at a Glance. $3^{\text {rd }}$ ed.UK.2012;50-51.

25. G, Bruna C, Benedetta M, et al. Prader-Willi Syndrome: Clinical Aspects. J Obes.2012:4739-41.

26. Mascarenhas JV, Ayyar VS,Russell Silver syndrome: a perspective on growth and the influence of growth hormone therapy. Indian $J$ Endocrinol Metab. 2012;16(5):840-2.

27. Noonan JA, Raaijmakers R,Hall BD.Adult Height in Noonan Syndrome. Am J Med Genet A.2003 Nov 15;123A(1):68-71.

28. Chang CY, Lin CY.Failure to thrive in children with primary distal type renal tubular acidosis. Acta Paediatr Taiwan. 2002 Nov-Dec;43(6):334-9

29. Pettifor JM.Nutritional Rickets.In Glorieux FH, Pettifor JM, Juppner H.Pediatric Bone: Biology \& Diseases. $2^{\text {nd }}$ ed.USA,2012;23: 642.

30. Bircan Z, Soran M, Yildirim I, et al. The effect of alternate-day low dose prednisolone on bone age in children with steroid dependent nephrotic syndrome. Int Urol Nephrol.1997;29(3):357-61.

31. Dost A, Rohrer T, Fussenegger J, Vogel $C$, Schenk B. Bone maturation in 1788 children and adolescents with diabetes mellitus type 1.J Pediatr Endocrinol Metab. 2010 Sep;23(9):891-8.

32. Önder A, Doğanci T, Çetinkaya E, Aycan Z.The evaluation of short stature and bone age in children with celiac disease.Turkish J. Pediatr. Dis. 2010; 4(4): 197-201.
33. Spadoni GL and Cianfarani S.usefulness of bone age in paediatric endocrinology, Italy. E-mail: stefano.cianfarani@uniroma2.

34. Garavelli L,Pedori S,Zanacca C, et al.Albright's Hereditary

Osteodystrophy(Pseudohypoparathyroidism Type Ia): clinical case with a novel mutation of GNAS1,Italy .Acta Bio med. 2005;76(1):45-8.

35.Zitelli et al. Atlas of Pediatric Physical Diagnosis.Rose, S. R. et al.Pediatricsin Review 2005;26:410-420.

36. Yee JK,Mao CS.Short Stature: Primary Hypothyroidism and Low Stimulated GH Response .Endocrine Follows Fundation2006; Vol13 (4).

37. Madhu SV,Jain $R$,Prakash V. Mauriac syndrome: A rare complication of type 1 diabetes mellitus.Indian J Endocrinol Metab. 2013; 17(4): 764-765.

38. Giovenale D, Meazza C, Cardinale GM, The Prevalence of Growth Hormone Deficiency and Celiac Disease in Short Children;Italia. Clin Med Res. 2006 Sep;4(3):180-3.

39. Bottazzo GF,Mcintosh C,Stanford W,Preece M.Growth hormone cell antibodies and partial growth hormone deficiency in a girl with Turner's syndrome.Clin Endocrinol (Oxf).1980;12(1):1-9 40. James C. M. Chan, Fernando Santos,Renal tubular acidosis in childhood.Portland, USA and Asturias, Spain .World J Pediatr 2007, Vol 3 No 2 .

41. Pedersen S. Do Inhaled Corticosteroids Inhibit Growth in Children? Denmark. Am J Respir Crit Care Med 2001.164:521535.

42. Eiholzer U, Bachmann S, l'Allemand D.Is there growth hormone deficiency in prader-willi Syndrome? Six arguments to support the presence of hypothalamic growth hormone deficiency in PraderWilli syndrome. Switzerland.Horm Res. 2000;53 Suppl 3:44-52

43. Allanson JE.Noonan syndrome.Am J Med Genet C Semin Med Genet.2007;145C(3):274-279.

44. Mahesh Sh., Kaske F.Growth hormone axis in chronic kidney disease,pediadric nephrology(2008);23(1):41-48.

45. Prasad NR, Reddy PA, Ahmed F .A rare case of Silver-Russell syndrome associated with growth hormone deficiency and urogenital abnormalities. Indian J Endocrinol Metab. 2012;16(2): S307-S309. 46. Kanazawa H, Tanaka H, Inoue M, et al. Efficacy of growth hormone therapy for patients with skeletal dysplasia.Journal of Bone and Mineral Meta 2003, Volume 21(5), pp 307-310.

47. Carpenter, T. O., Imel, E. A., Holm, I. A., et al . A clinician's guide to X-linked hypophosphatemia. J Bone Miner Res, 2011.26: 1381-1388. 